\title{
Physical exercise to reduce cardiovascular disease risk
}

\author{
Ralph Paffenbarger \\ Department of Health Research and Policy, Stanford University School of Medicine, HRP Redwood Building, \\ Room T213B, Stanford, CA 94305-5405, USA
}

The modern story of exercise and cardiovascular disease began in 1949 when Jeremy N. Morris and colleagues (Morris et al. 1953a,b) first began to understand how both vocational and leisure-time physical activity relate to fitness and risk of CHD. They studied London transit workers, postal service employees and civil servants. Initially they found bus conductors on London's double-decker omnibuses to be at lower risk than bus drivers; what disease the conductors did develop was less severe, and they were more likely to survive an attack.

More recently, Morris et al. (1990) studied a random sample of 3591 British civil servants who were followed over an 8-year period ending in 1977, during which time 268 men died. Subjects were classified as having engaged in vigorous activities (requiring $\geq 35.1 \mathrm{~kJ}(7.5 \mathrm{kcal})$, i.e. $\geq 6$ metabolic equivalents of energy output), or not. Of the subjects $22 \%$ reported some kind of vigorous exercise and their death rate was 4.2 per 100 . The remaining $78 \%$ reported no vigorous exercise and their mortality rate was twice as high, i.e. 8.4 per 100 . This differential in death rates persisted when account was taken of age, smoking, obesity and successive intervals of follow up.

A myriad of other populations have been studied for physical activity and physiological fitness in relation to health (US Department of Health and Human Services, 1996). Here we describe a study of 17549 men who entered Harvard College between 1916 and 1950 (Paffenbarger et al. 1978), and when aged 55-84 years responded to a 1977 questionnaire on their personal characteristics, health status and lifestyle habits. These patterns have been related to cardiovascular disease mortality over a 16-year follow-up period, 1977-1992, when 1856 men died (Paffenbarger et al. 1986a,b; Paffenbarger \& Lee, 1999).
Among Harvard alumni there were strong significant associations between lower death rates and higher levels of each of the following: walking, stair climbing, sports play and combinations of these activities, measured in $\mathrm{kJ} / \mathrm{week}$. Gradients of benefit from more active lifestyles were consistent throughout, and were independent of age, smoking, hypertension and obesity. As compared with the one-third of men least active, the middle third of men experienced a $23 \%$ reduction in death rate during follow up and the one-third of men most active, a $32 \%$ reduction. Light activities (requiring < 4 metabolic equivalents of energy output), moderate activities (4-5 metabolic equivalents of energy output), and vigorous activities ( $\geq 6$ metabolic equivalents of energy output) each predicted lower death rates.

These men were studied for the effect on all-cause mortality from changing physical activity habits. Men who had increased or decreased their activity by less than $1032 \mathrm{~kJ}(250 \mathrm{kcal}) /$ week between the 1960s and 1977 were considered in an 'unchanged' category. Compared with their death rates, gradient reductions in mortality were observed with increased levels of physical activity, and gradient increases in mortality with decreased levels of activity. At the extremes of this gradient, men who had increased their energy expenditure by $\geq 5160 \mathrm{~kJ}(1250 \mathrm{kcal}) /$ week had a $20 \%$ lower risk of death than men in the unchanged category; men who decreased their activity by $5160 \mathrm{~kJ}$ $(1250 \mathrm{kcal}) /$ week had a $26 \%$ higher risk (Paffenbarger et al. 1993, 1994).

Vigorous activity should be encouraged. In today's world, where time is a precious commodity, one $0.5 \mathrm{~h}$ period of vigorous exercise expends as much energy as does moderate activity carried out for two or three times as long.

\section{Cardiovascular disease: Physical activity: Death rate}

\section{References}

Morris JN, Clayton DG, Everitt MG, Semmence AM \& Burgess EH (1990) Exercise in leisure time: coronary attack and death rates. British Heart Journal 63, 325-334.
Morris JN, Heady JA, Raffle PAB, Roberts CG \& Parks JN (1953a) Coronary heart disease and physical activity of work. Lancet ii, 1053-1057.

Morris JN, Heady JA, Raffle PAB, Roberts CG \& Parks JN (1953b) Coronary heart disease and physical activity of work. Lancet ii, $1111-1120$. 
Paffenbarger RS Jr, Hyde RT, Wing AL \& Hsieh C-c (1986a) Chronic disease in former college students: XXX. Physical activity, all-cause mortality, and longevity of college alumni. New England Journal of Medicine 314, 605-613.

Paffenbarger RS Jr, Hyde RT, Wing AL \& Hsieh C-c (1986b) Chronic disease in former college students: XXX. Physical activity, all-cause mortality, and longevity of college alumni. New England Journal of Medicine 315, 399-401.

Paffenbarger RS Jr, Hyde RT, Wing AL, Lee I-M, Jung DL \& Kampert JB (1993) Chronic disease in former college students: XXXVII. The association of changes in physicalactivity level and other lifestyle characteristics with mortality among men. New England Journal of Medicine 328, $538-545$.

Paffenbarger RS Jr, Kampert JB, Lee I-M, Hyde RT, Leung RW \& Wing AL (1994) Chronic disease in former college students: LII. Changes in physical activity and other lifeway patterns influencing longevity. Medicine and Science in Sports and Exercise 26, 857-865.

Paffenbarger RS Jr \& Lee I-M (1999) Age-specific physical activities and lifeway patterns as related to all-cause mortality and to longevity. In Exercise for Preventing Common Disease, pp. 121-130 [H Tanaka and M Shindo, editors]. Fukuoka, Japan: Springer-Verlag.

Paffenbarger RS Jr, Wing AL \& Hyde RT (1978) Chronic disease in former college students: XVI. Physical activity as an index of heart attack risk in college alumni. American Journal of Epidemiology 108, 161-175.

US Department of Health and Human Services (1996) US Department of Health and Human Services: Physical Activity and Health: A Report of the Surgeon General. Atlanta, GA: United States Department of Health and Human Services, Centers for Disease Control and Prevention, National Center for Chronic Disease Prevention and Health Promotion. 